\title{
To See Invisible Rights: Quantifying Araman informal tenure and its immediate relationship with Social Forestry in Central Java, Indonesia
}

\author{
Alex Cummins ${ }^{1 *}$, Eiji Yamaji ${ }^{1}$ \\ 1 The University of Tokyo \\ * Corresponding author: 7805710276@edu.k.u-tokyo.ac.jp
}

\begin{abstract}
The process of formalizing traditional, unwritten tenure systems is no simple task. Inaccurate or incomplete representation of the informal system may create more problems for the local communities. As such, a full understanding of the local informal tenure systems is necessary before implementing any type of land reform. This paper discusses a case study conducted in the Tawanmangu area of Central Java, Indonesia, in which the informal system known as Araman is quantified on paper with the help of the Tenure Map tool, survey, and interview. The challenges of quantifying and understanding an informal system are discussed with the following viewpoints: key aspects of the Araman structure, the relationship between the informal Araman system and the formal Social Forestry system also present in the area, and finally comments on the strengths and weaknesses of the Tenure Map tool after using it in the field.
\end{abstract}

Keywords: tenure; informal; property rights; Social Forestry; decentralization; Indonesia

\section{Introduction}

Recent literature defines informal tenure as a system of ownership that is developed and upheld by traditional communities around the world, based on ancestral practices and knowledge specific to the community's geographic area. However, the most distinguishing trait of informal rights is that they are unwritten and undocumented (Schlager and Ostrom, 1992; Chao, 2012). In general, legal terms, informal rights are referred to as de facto rights, meaning they are not formally recognized on paper, but they are practiced in 'fact' on the ground level. This does not make them illegal. It is the opposite of de jure, which means something that is formally defined and is accepted on paper by governing institutions. In short, if rights are written and enforceable by a government, they are known as de jure. If they are not recognized by the government or authorities, yet defined and enforced among the local community, then they are known as de facto rights. As a result, de facto, or informal, tenure rights have been difficult to uphold in a legislative setting (Schlager and Ostrom, 1992).

Despite this, informal rights are in many cases essential to forest people's livelihood, especially in Southeast Asia (Chao, 2012). As such, there are many efforts to improve the reliability of forest people's informal tenure systems. One solution is to directly formalize them by granting a title to the community or land owner. If a title is granted, the rights of customary communities would no longer be informal, and would be easier to defend. But it is not so simple. Informal rights are de facto and as such are not defined, meaning they may not be concrete enough to map before the courts (Schlager and Ostrom, 1992). If informal tenure rights are to be formally recorded, they should first be finalized on the ground level in order to be properly represented on paper, as it must withstand a long and expensive legal process (Siscawati et al., 2017).

Unfortunately, this does not work well for informal systems, which can be very flexible according to local needs and conditions. This is known as fluidity (Barry et al., 2010), which refers to the unfixed nature of resource rights and usage. For example, rights may vary by season or drought to mitigate environment change. Furthermore, most tenure reforms around the world are based on foreign or colonial concepts of ownership in which land parcels are owned by the 
individual holding a private title. This idea rarely matches with communities' traditional ownership systems (Van Der Eng, 2016). In many cases, especially Southeast Asian forest communities, the absolute ownership of land is not truly transferred to the individual but remains with the state (Maryudi et al., 2016).

In these cases, original informal claims to resources can overlap with other communities, companies, or formal state land. Solving this overlap of claims poses a great challenge when drafting conventional maps, as is usually needed for the process of formalization, because it is difficult to accurately represent the informal rights and who holds them. Even community managed participatory mapping is not enough (Barry et al., 2010).

As a result, failing to properly understand an informal tenure system could lead to unintentional exclusion of traditional right-holders during a land reform process. This is a serious consequence, as many of these people's livelihoods depend on their traditional or de facto rights to natural resources. This is something that maps cannot identify. As such, it is essential to not only bring attention to informal systems of tenure and resource use in the case of land reform, but to properly understand informal rights through the accurate quantification of them on paper as they have not been represented that way before.

\section{Target Area Indonesia}

Indonesia is a country in which two thirds of its area is covered by forest. All of this land is classified as forestland and belongs to the state government. On Java Island, the state government manages this forestland via a state-owned forest company called Perhutani. However, much of the land classified as 'state forestland' is occupied by customary communities. In 2012, Indonesia was ranked as the country with the highest population of customary rights users (referred to as Forest People) in East and South East Asia, at around 80 - 95 million people (Chao, 2012). These customary communities can manage and occupy statutory forestland without a private title by using de facto rights, as they have been doing for generations.

Because of this, many of these communities cannot uphold their claims in court and are involved in overlapping tenure claims with the MOEF. As the formal land owner, the MOEF has the right to use and permit activities in state forestland that is also considered to be the community's traditional territory, sometimes resulting in conflict (Siscawati et al., 2017). There have been frequent instances of land grabbing and illegal logging in customary land, with adverse impacts to these communities (Maryudi et al., 2016).

Recent initiatives to reduce these conflicts and resolve overlapping claims aim to reorganize forestland rights by distributing formal titles. However, this issuance of formal titles may be difficult for small communities. The legal process of just obtaining a permit in Indonesia requires up to 26 steps and can take up to three years, as the application must pass through agencies at every level from village to national and requires skilled technical work such as mapping and socioeconomic analysis before being approved (Siscawati et al., 2017). Furthermore, the cost to register property in Indonesia is $10.8 \%$ of the property value, which is the most expensive in Asia (The World Bank, 2017).

\section{How to Recognize Informal Tenure in Indonesia?}

An alternative to formal privatization was proposed by the Indonesian government in 1999. This initiative, known as Forestry Law No.41, aims to simply recognize informal tenure rights, but not privatize them. This law introduced a program called Social Forestry for the use of customary communities. Social Forestry schemes do not grant titles but allow local communities to obtain licenses for forest use and management. Full ownership of the forestland still rests with the state entity. In short, the MOEF recognizes the existence of customary forestland, and offers the opportunity for partial rights to the land. 
With this system, traditional communities may uphold their de facto rights without receiving ownership of the land itself. As of 2017, there are several different schemes under Social Forestry, varying based on location or political situation. The four most common schemes are Community Law Forest (Hutan Kemasyarakatan or HKm), Village Forest (Hutan Desa or HD), Community Timber Plantation (Hutan Tanaman Rakyat or HTR), and Forest Partnership (Kemitraan) (Siscawati et al., 2017). In 2015, the President of Indonesia pledged 12.7 million hectares of forestland to be allocated for Social Forestry by 2019 (MOEF, 2017). This system theoretically offers the best of both worlds: traditional rights are upheld, while the state retains management and ownership of the forestland. In most cases, it appears to succeed at doing so (Banjade et al., 2017).

However, Social Forestry is not perfect. Recent studies also show that Social Forestry may fail to uphold traditional rights of the local people if it does not accurately reflect their relationship with the land they use (Moeliono et al, 2017). In order for local communities to reap the benefits of recognition by an external formal entity, their informal system must first be accurately recognized, despite the fact that it is not written and is easily influenced by external changes (Schlager and Ostrom, 1992). In fact, previous case studies of Social Forestry in Indonesia revealed local entities are increasingly gaining momentum and support for their own activities, which are sometimes illegal, and may conflict with the Social Forestry scheme put in place by the state (Mahdi et al., 2017; Maryudi et al., 2016). In these cases, Social Forestry did not support the local communities' existing way of life, leading them to act against it.

As such, this paper aims to contribute a case study examining the process of formalizing an informal tenure system, while simultaneously staying conscious of the vulnerability of informal systems to the process of quantification when being crystalized on paper. The result of this study will outline the relationship between a traditional informal rights system and the formal system of Social Forestry being introduced. Any changes imposed upon the local informal system due to Social Forestry will be noted. Suggestions concerning the process of defining a previously unwritten, informal tenure system on paper will also be given, with emphasis on the use and challenges of implementing the Tenure Map tool in the field. This information is of value to any researcher or organization that wishes to work with informal rights holders and communities while preserving their local way of life, as Social Forestry aims to do.

\section{Methods: Case Study, Process, and Tenure Map}

\subsection{Case Study: the Araman system}

To practice quantifying an informal system, a case study was conducted in the area near Sekipan Tawangmangu Park, located on the eastern border of the Central Java province. This area adopted Social Forestry in August 2017, under the scheme of Village forest, or Hutan Desa (HD). This forestland area is state-owned and contains mainly Sumatran pine trees (pinus merkusii), acacia, grasses, and shrubs. The Sumatran pines are strictly protected. A minimum fine of 500,000 rupiah will be given if it is cut down. The maximum fine is $500,000,000$ rupiah and a prison sentence of 3 months to 2 years.

Despite these rules, the forest is frequently occupied and relied on by peasant farmers for harvests of grass and acacia timber. The grass can be sold for livestock feed, and the acacia may be sold for use as kitchen fuel. These crops grow quickly, are low maintenance, and help to diversify the forest in which most of the trees are Sumatran pines. These activities are acceptable to authorities as long as the farmers do not disturb the Sumatran pines.

However, the farmers of this area must also hold informal tenure rights within their community in order to harvest these crops. This system of informal tenure is known locally as Araman. This word is used by local people to mean "land undertaken by the community for generations, only to search for grasses and plants of certain tree species". This means there is no 
written certification; instead, everyone in the community knows who can use each area of land, as it has been that way for many generations. It was estimated that about $70 \%$ of local people in the area have Araman rights, although the exact number is not officially recorded.

\subsection{Process}

The process of quantifying the Araman system was structured as follows: first, an in-depth interview was conducted with key informant of Sekipna park and surrounding forestland area. The objective of this interview is to understand the Social Forestry scheme in the area and how the local system nests within it.

Second, a survey was conducted among local individuals who use the Araman system, to identify which rights Araman users hold or lack. The structure of rights inquired about by this survey is taken from Schalger and Ostrom (1992) in which informal rights are defined and grouped into bundles as follows:

- Withdraw: gather or harvest, pick some plants

- Access: route to walk across field

- Exploit: economic benefit, can sell and decide price

- Manage: decide what to grow or cut, where to graze

- Exclusion: prevent others from accessing or using field or forest

Finally, a Tenure Map was drafted based on the combined responses of both the interview and the survey, as described in the following section.

\subsection{Tenure Map}

The Tenure Map is a theoretical tool which aims to visually represent the structure of rights and players of an informal, or "invisible", tenure system, and its relationship with the surrounding formal structures, by clarifying them on paper. The Tenure Map was suggested by Barry et al. (2010) and borrows the bundles of informal rights from Schlager and Ostrom as was also used in the structure of the survey, described in the previous section.

The goal of the Tenure Map is to provide a full understanding of the allocation of, and relationships between, formal or informal rights in any form of tenure system. It is structured as follows:

- Players are identified on a spectrum from government level to individual level along the $x$-axis.

- Rights that each player may hold, from simple use rights to full ownership, are identified along the $y$-axis.

- The intersection of players and rights indicates the relationship between each player in the tenure system.

From this it is clear which rights each player possesses. This may be done for current and past situations, and the comparison of these will reveal how the rights have changed since a given date, giving users a chance to track changes in allocation of rights or power that may have occurred during land or structural reform (Barry et al., 2010). Some examples of situation for which it may be useful include cases in which ownership of state land are transferred to local communities, or when forests are newly designated for use by local communities and indigenous peoples via permits or licenses.

It also provides freedom when identifying players, as they can be defined and placed on a continuum from public level to grassroots level according to the local context, rather than the three textbook categories of public, private, common. Overlap of rights between players is also possible.

In contrast to conventional mapping methods, such as spatial mapping or participatory community maps showing external boundaries, the Tenure Framework is not a spatial representation of a physical area. Instead it is a representation of bundles of tenure rights in 
relation to natural resources and players of the local system. This aims to give a more complete understanding of access, use, and decision-making rights when analyzing changes in informal rights. This is important when considering use of resources and land governance and provides more perspectives than conventional maps. This is valuable since the process of changes to rights allocation and governance and its impacts are usually separately studied (Van Vliet et al., 2016).

\section{Results}

\subsection{Interview}

During the interview, it was revealed that there is no governing body for holders of Araman rights. In fact, the "holders and areas are decided historically", because owners have generally held them since traditional times and passed the rights down through many generations. Furthermore, rights to Araman areas are not shared, in fact, the areas are private.

Further discussion revealed technical details about the Araman system, such as the method for transfer and acquisition of rights to an area, the ability of an Araman holder to transfer or relocate his rights, and how transactions are handled considering the lack of any Araman authority or governing body. These details are depicted in the following figure (Figure 1):

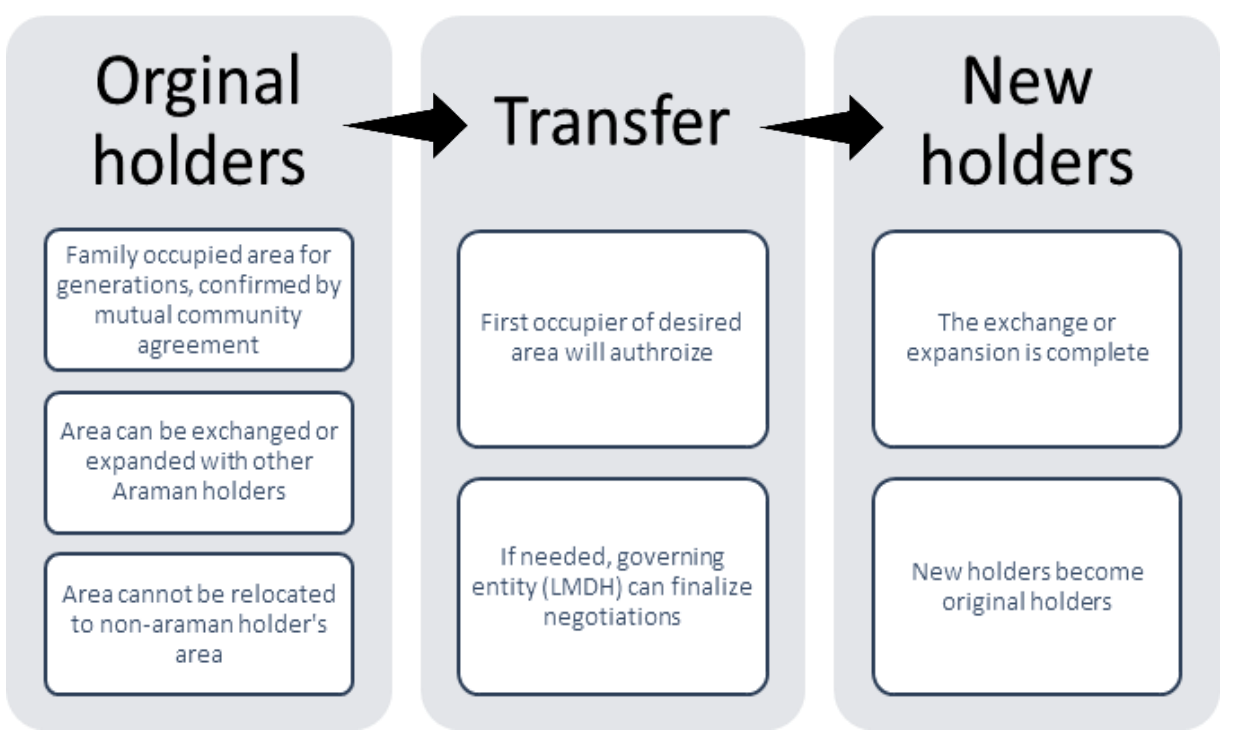

Figure 1: Araman system

As seen in Figure 1, Araman areas are decided by mutual agreement within the community, as there is no governing body. In some cases, Araman users can give permission to non Araman users to use their area of land. They can also expand, transfer, or exchange their areas with other Araman rights holders. In this case, the first person who managed that land will authorize the transfer. The local government, $\mathrm{LMDH}$, can step in if needed in a bad situation. However, this cannot be done between non-Araman holders or private land owners.

\subsection{Tenure Map}

The following changes were observed and noted with the creation of the tenure map (see Figure 2). 


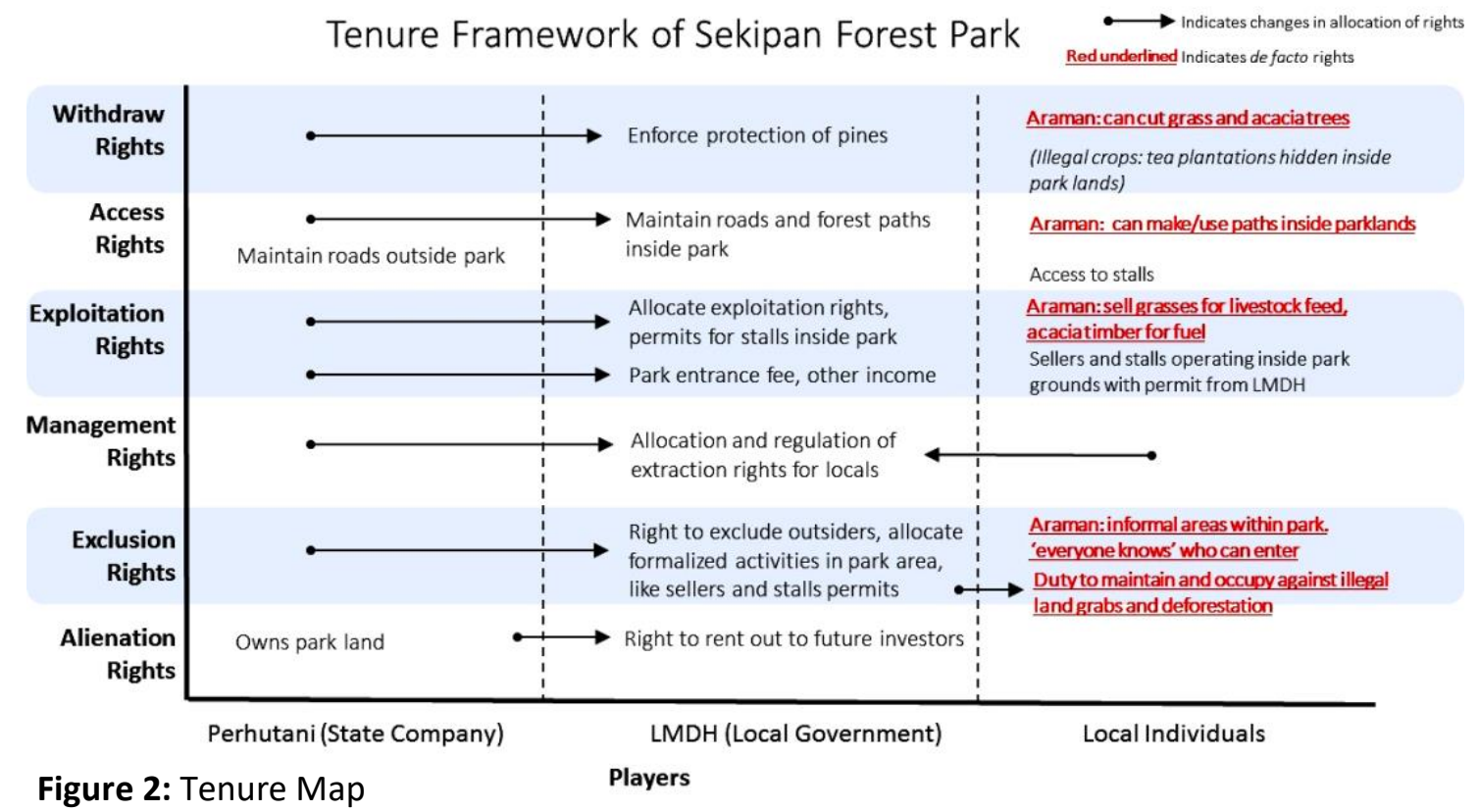

The Tenure Map identified 3 players: state level (Perhutani), local community level (LMDH or Lembaya Hlasyaklat Desa Hutan/Community Social Village Forest), and individual level (both Araman and non-Araman users). Originally the forestland was managed completely by Perhutani. In August 2017 it became a Village forest, at which time the local government received responsibility over several bundles of rights. Power was shifted from state to the local government by contract which can be renewed every 2 years.

This is reflected in the tenure map by the shifting of many duties from the left to the center, indicating that Perhutani now assigns these duties to the local government LMDH. Nearly all other bundles of rights have been transferred from state entity Perhutani to local government entity (LMDH). This includes access, use, withdrawal, management, and exclusion.

\subsection{Changes Imposed upon Informal System Since the Introduction of Social Forestry}

In fact, Araman informal rights remain relatively unchanged. On the local level, the de facto rights ensure access, exploitation, management, exclusion rights to areas for cutting grass and acacia fuel. There was one instance of illegal crops being harvested in the park (tea plants).

Only one instance of rights being transferred to the individual level exists. This is the responsibility of maintaining the area against illegal land grabs. According to the survey of local people, this is generally understood as being accomplished by keeping the area occupied or maintaining a presence in the area in order to deter illegal loggers and land grabs. The Araman holders expressed a duty to uphold this responsibility. Local individuals who did not hold Araman rights also expressed the importance of Araman forest occupation in this regard. The Tenure Map indicates that this duty was strengthened as a result of Social Forestry introduction in the area. 


\section{Conclusion: Challenges Imposed by Social Forestry}

\subsection{Challenges}

The changes outlined in the previous section should also be noted in accordance with the impacts, impressions, and stresses, that they caused towards the original system. Although it has only been a short time since the park became a Village forest, local people (both Araman and nonAraman holders) have already expressed displeasure with the new LMDH management of the park. This is mainly due to LMDH neglecting the wishes of original residents who lived there for many years. Some issues were also raised over the maintenance of roads and public areas that became unkept since LMDH took charge. Respondents expressed concern that the LMDH was only interested in gathering income from tourism in the forest park area. In the words of one interview respondent: "forest should be just for forest, not for money".

\subsection{Source of Challenges}

One possible source of these stresses is how Social Forestry seems to treat the Local Government and the local individuals as one unit, when in fact they are quite distinct. Araman users are members of a generations-old, traditional rights system; their rules and goals are quite different from that of the Local Government. During the interview and survey, it was clear that LMDH and Araman users were entirely separated from one another as members of one group referred to the other as if they were outsiders and different from themselves.

This distinction seems to have been reinforced among themselves by the introduction of Social Forestry in the area, as the LMDH has been recognized as a representative of local people and has been given many responsibilities. However, the Araman rights holders are still local individuals, and their consultation depends on the relay of information to Perhutani via LMDH. This is despite the goal of Social Forestry, which is to empower holders of informal rights by recognizing their traditional claims to forestland and upholding their way of life.

Another possible source of stress that may have been exacerbated by the adoption of Social Forestry is that the values of the Araman system are not well understood by others. For example, according to a non-Araman member of the local community, the goals of each player are as follows: Perhuntani wants to protect the forest, LMDH wants to exploit tourism and gain publicity and attention on social media, and Araman individuals want use wood and forest resources, as they have been doing for many years. However, when asking the Araman rights holders directly about themselves, their views differed. They expressed pride in the strengthened duty to protect the forest via occupation and responsible forest use, as well as monitoring natural resources like water and forest flora. This view is quite different from simply using forest resources. Whether exaggerated or truthful, this self-identity deserves to be heard by Perhutani and perhaps could be incorporated into the Social Forestry scheme of that region if it agrees with the general objectives of the Social Forestry program.

These problems could potentially be solved by facilitating direct communication between Perhutani and Araman, and by treating Araman holders as if they are on the same player level as $\mathrm{LMDH}$. The first step towards this goal must then be to identify Araman holders as separate from $\mathrm{LMDH}$, but still on equal footing in terms of player level in negotiations.

\section{Formalizing the Informal: Comments on Using the Tenure Map Tool}

There was some difficulty in classifying the informal Araman rights into the bundles defined by Schlager and Ostrom when using the Tenure Map. Although the bundles are clearly defined, the two most complex rights (Management and Exclusion) only exist within the Araman system between its users. They cannot apply to non-Araman holders. Also, they must be in compliance 
with the formalized system put in place by the governments. In this survey, it would have been much simpler to cut those bundles from the local level of the Tenue Map, and instead incorporate those rights under the simpler bundles of Withdraw, Access, and Exploitation.

For example, Access is defined as the right to cross field or forest. Exclusion is also upheld within the Araman system as it gives ability to exclude other Araman users from their private areas. However, it does not give them authority to prevent outsiders from entering. Because of this, it was difficult to classify these rights as purely Exclusion. In the future, they may be better classified under Access, since they are only valid among the Araman system users themselves. Exclusion can then be removed.

Another observation made when defining the Araman system was the importance of identifying the key value of each player, as well and the theoretical structure of the informal system, both of which are not required in the creation of the Tenure Map. For example, comparing the values or goals of each player, as seen by others versus themselves, served as a very important part of investigating why the relationship between Araman and LMDH was strained.

In future studies, the values of each player should be identified according to themselves and each other, as shown in Table 1 below. Identifying common goals, as well as differences between 'view of self' and views from others towards the same player, can be used to improve relationships between players and reduce misunderstanding of what each group wants, despite their reputation. This would also lead to the discovery of common or conflicting values, which could then be used to improve relationships and form compromises.

Table 1. Template for Understanding the Views of Each Player Towards Each Other

\begin{tabular}{|c|c|c|c|}
\hline & Player \#1 & Player \#2 & Player \#n \\
\hline Player \#1 perspective & View of Self & $\begin{array}{c}\text { Goal of Player \#2 } \\
\text { according to Player \#1 }\end{array}$ & $\begin{array}{c}\text { Goal of Player \#n } \\
\text { according to Player \#1 }\end{array}$ \\
\hline Player \#2 perspective & $\begin{array}{c}\text { Goal of Player \#1 } \\
\text { according to Player \#2 }\end{array}$ & View of Self & $\begin{array}{c}\text { Goal of Player \#n } \\
\text { according to Player \#2 }\end{array}$ \\
\hline Player \#n perspective & $\begin{array}{c}\text { Goal of Player \#1 } \\
\text { according to Player \#n }\end{array}$ & $\begin{array}{c}\text { Goal of Player \#2 } \\
\text { according to Player \#n }\end{array}$ & View of Self \\
\hline
\end{tabular}

Without this table, the Tenure Map was barely able to incorporate much of the information obtained during the interview, despite its proclaimed flexibility. Important points like the structure of Araman system, and the goals of each player, had no place in the Tenure Map, even though they proved vital to understanding the Araman informal tenure system. In future studies of informal tenure the structure of the informal system (Figure 1 ) as well as the goals of each player (Table 1) should both be sketched out, in addition to the Tenure Map. With this information, informal tenure systems have a better chance of being fully recognized and understood.

\section{References}

Banjade, M. R., Liswanti, N., Herawati, T., Mwangi, E. (2017). Outcomes of land and forest tenure reform implementation in Indonesia. World Bank Conference on Land and Poverty, Washington DC, March 20-24, 2017.

Barry, D., Meinzen-Dick, R. (2010). The invisible Map: Community Tenure Rights. Book: The Social Life of Forests, University of Chicago Press

Chao, S. (2012). Forest Peoples: Numbers across the world. UK: Forest Peoples Program. 
http://www.forestpeoples.org/sites/fpp/files/publication/2012/05/forest-peoplesnumbers-across-world-final_0.pdf

Mahdi, Shivakoti, G., Inoue, M. (2017). Decentralization of Forest Management, Local Institutional Capacity, and Its Effect on Access of Local People to Forest Resources: The case of West Sumatra, Indonesia. In Redefining Diversity \& Dynamics of Natural Resources Management in Asia, Volume 1 (pp. 305-319). doi: https://doi.org/10.1016/B978-0-12-805454-3.00016-5

Maryudi, A., Citraningtyas, E. R., Purwanto, R. H., Sadono, R., Suryanto, P., Riyanto, S., \& Siswoko, B. D. (2016). The emerging power of peasant farmers in the tenurial conflicts over the uses of state forestland in Central Java, Indonesia. Forest Policy and Economics, 67, 70-75. doi: https://doi.org/10.1016/j.forpol.2015.09.005

MOEF. (2017). Social Forestry in Indonesia [Brochure]. Indonesia.

Moeliono, M., Thuy, P., Waty Bong, I., Wong, G., \& Brockhaus, M. (2017). Social Forestry - why and for whom? A comparison of policies in Vietnam and Indonesia. Forest and Society, 1(2), 7897. doi: http://dx.doi.org/10.24259/fs.v1i2.2484

Schlager, E., \& Ostrom, E. (1992). Property-rights regimes and natural resources: a conceptual analysis. Land economics, 249-262. doi: http://dx.doi.org/10.2307/3146375

Siscawati, M., Banjade, M. R., Liswanti, N., Herawati, T., Mwangi, E., Wulandari, C., Tjoa, M., \& Silaya, T. (2017). Overview of forest tenure reforms in Indonesia (Vol. 223). CIFOR.

The World Bank. (2017). Brief: Land. Retrieved from http://www.worldbank.org/en/topic/sustainabledevelopment/brief/land.

Van Der Eng, P. (2016). After 200 years, why is Indonesia's cadastral system still incomplete? Canberra, Australia: Australian National University.

Van Vliet, J., Magliocca, N. R., Büchner, B., Cook, E., Benayas, J. M. R., Ellis, E. C., ... \& Mertz, O. (2016). Meta-studies in land use science: Current coverage and prospects. Ambio, 45(1), 1528. doi:https://doi.org/10.1007/s1328 